\title{
Correlation of Hypoxia-Inducible Factor-1a Level with Control Glycemic in Type 2 Mellitus Patients with Malignancy and Without Malignancy
}

\author{
Rusdiana Rusdiana $^{1 *}$, Maya Savira ${ }^{2}$, Kamal Basri Siregar $^{3}$, Sry Suryani Widjaja ${ }^{1}$, Dedi Ardinata ${ }^{2}$ \\ ${ }^{1}$ Department of Biochemistry, Medical Faculty, Universitas Sumatera Utara, Jl. Dr. Mansur No. 5, Medan, Indonesia; ${ }^{2}$ Department \\ of Physiology, Medical Faculty, Universitas Sumatera Utara, Jl. Dr. Mansur No.5, Medan, Indonesia; ${ }^{3}$ Department of Surgery, \\ Oncology Subdivision, Faculty of Medicine, Universitas Sumatera Utara, Medan, Indonesia
}

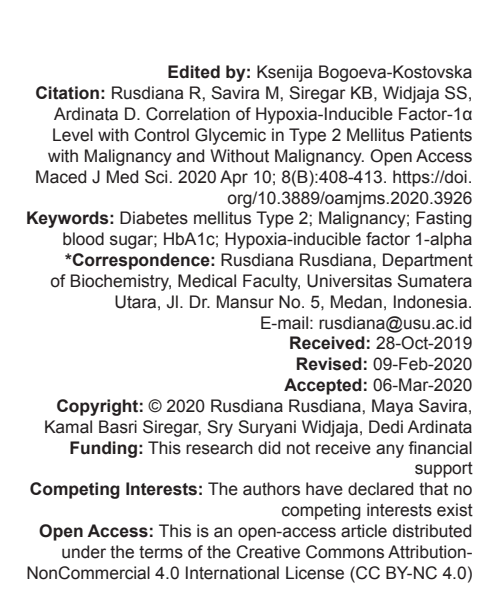

Introduction

Diabetes mellitus (DM) is a chronic metabolic disease caused by the body's inability to produce insulin hormone as needed or due to the ineffective use of insulin or both. This is characterized by high blood sugar levels (hyperglycemia). At present, there is an increase in the prevalence of DM throughout the world. DM is known as a key factor contributing to the development of malignancies from solid organs, including the liver, pancreas, rectal colon, breast, endometrium, uterus, and bladder [1]. In 2013, there were 382 million people in the world aged 40-59 years suffering from DM, and it is estimated that it will continue to increase every year. Regional International Diabetes Federation data show that Southeast Asia is ranked the second-highest in the world with a total DM population of 72 million. In 2035, it is estimated that this figure will increase by $70.6 \%$ to 122.8 million; this increase in the prevalence of DM occurs throughout the world in both developed and developing countries [2], [3].

\begin{abstract}
BACKGROUND: Type 2 diabetes mellitus (T2DM) is becoming increasingly prevalent worldwide. Malignancy is one an increase in blood glucose levels (hyperglycemia) which will cause tissue hypoxia which can lead to malignancy. samples of the T2DM patients with malignancy and T2DM without malignancy. who attended Murni Teguh Hospital in Medan of Indonesia country. The inclusion criteria of the samples were all the (2DM with or without malignancy, both the sexes. Body mass index, blood pressure, diseas history, and socioeconomic status were recorded. The laboratory parameters, including fasting blood sugar (FBS)

RESULTS: In this study, we found that there was no significant correlation between HIF-1 $\alpha$ with FBS and HbA1c (005), but we found that there was a significant correlation HbA1c with FBS $(p<0.005)$

N: The results of the study revealed HIF-1 $\alpha$ at the both of the group of the samples even in the relative small amounts until a large amounts in the serum, but we found that there was no correlation significantly betwee HIF-1 $\alpha$ and glycemic index (HbA1c and FBS), while there was correlation significantly between Hba1c and FBS.
\end{abstract}

The number of diabetics in Indonesia is ranked $7^{\text {th }}$ in the world. At present, the prevalence of diabetes in Indonesia, which doctors have diagnosed, is $1.4 \%$, this number is expected to continue to increase (Riskesdas, 2013). The WHO estimates that $21,527,000$ Indonesians will suffer from DM by 2030 [4]. DM is characterized by defects in hypoxia-induced neovascularization in the myocardium, skeletal muscle, nerves, and skin. Inadequate collateral vessel formation in response to ischemia increases cardiovascular morbidity and mortality in diabetic patients [5]. DM and malignancy are frequently diagnosed in the same individual [6]. The mechanism for the diabetes-cancer link has been hypothesized to be mainly related to hormonal insulin and insulin-like growth factor (IGF)-1, inflammatory, or metabolic (hyperglycemia) characteristics of the DM and even to certain treatments [7]. Antidiabetic medications may have effects on the risk of cancer. Many studies found that diabetes was consistently related to increased risk for a broad variety of malignancies, and the prospective researches reported that there was a relation of increased blood glucose with 
increased overall cancer incidence and that postulated as a linear trend of increased blood glucose levels and cancer risks [8]. Several large cohort and case-control studies have found a positive relationship between hyperglycemia and the risk of cancer [9] and the other researches that a meta-analysis comprising 30 cohort studies showed that diabetes was associated with an increase in the risk of colorectal cancer [10], [11].

Cancer occurs in a condition, where the cell has lost its normal control and mechanism, resulting in abnormal growth [12]. Although the science is increasingly sophisticated, until now, it is not known with certainty the main cause of breast cancer, which is estimated to be very multifactorial [13]. Diabetes with malignancy is a common disease with extraordinary health impacts throughout the world [14]. Epidemiological evidence showed that people with diabetes have a significantly higher risk of developing malignancy [15]. Type 2 diabetes mellitus (T2DM) and malignancy have many risk factors, but the potential biological relationship between the two diseases is not fully understood. Moreover, evidence from observational studies showed that some drugs used to treat hyperglycemia are associated with an increase or decrease in cancer risk; [16] there are a variety of antidiabetic interventions, including sulfonylureas, a-glucosidase inhibitors, biguanides, and thiazolidinediones (TZDs) [17] that increase the level of circulating insulin, thereby reducing hyperglycemia by various mechanisms. Metformin inhibits cell proliferation and induces apoptosis in cancer cell lines [18], whereas metformin and other biguanides decrease the cancer incidence [19] that some confounding factors are directly related to the clinical diversity of diabetes levels at the level of metabolic control, duration of diabetes, antidiabetic therapy profile, and the presence of complications or comorbidities [19]. A number of the factors that contribute to the increased risk of developing cancer in T2DM include hyperglycemia, insulin resistance, hyperinsulinemia, increased levels of IGF-1, dyslipidemia, cytokines, increased leptin, and decreased levels of adiponectin [20], [21], [22].

Recently, many studies improved that DM is often associated with hypoxia which damages induced neovascularization during the process of ischemia and other forms of cell response and adaptive tissue to low oxygen levels [23]. Hyperglycemia seems to be the driving force for such deregulation. Recent data on destabilization of hypoxia-inducible factor-1-alpha (HIF-1 1 ) are likely to be events that hyperglycemia loss cellular response to hypoxia in most diabetes complications [24]. HIF-1 $\alpha$ was a master regulator that mediates the cellular response to hypoxia [25] so that has been proven that HIF-1 $\alpha$ plays a role in the pathogenesis of malignancy too. Due to that, this aim study wants to know how the correlation about the HIF-1 $\alpha$ with the control glycemic in type 2 mellitus patients with malignancy and without malignancy.

\section{Materials and Methods}

\section{Subjects}

We included 89 of the samples, consecutive T2DM with malignancy and T2DM without malignancy, between January and July 2019, who attended to Murni Teguh Hospital in Medan, North Sumatera, Indonesia, according to ADA and the WHO guidelines. The samples was composed of all T2DM with or without malignancy, both male and female, without the exception the age and treatment. Exclusion criteria were type 1 DM and severe disease. Physical examinations were performed to record patient demographics, including height, weight, body mass index (BMI), and blood pressure. Biochemical tests were done as fasting blood sugar (FBS) and HbA1c. All participants were provided written informed consent at the visits and explain of the examination for the samples and this study was in compliance with the Declaration of Helsinki. Our study was approved by our Institutional Health Research Ethics Committee with number 484/ TGL/KEPK FK USU-RSUP HAM 2019.

\section{Biochemical measurements}

Before the blood samples were collected at a visit to the outpatient clinic, the samples must fast overnight. The blood of the samples was centrifuged at $3000 \mathrm{rpm}$ at $4^{\circ} \mathrm{C}$ for $15 \mathrm{~min}$. The supernatants were decanted and frozen at $-80^{\circ} \mathrm{C}$ until assayed. FBS and $\mathrm{HbA} 1 \mathrm{c}$ were measured using standard methods. FBS was examined by the machinery portable measuring instrument (Gluco DR) and $\mathrm{HbA} 1 \mathrm{c}$ was measured by the HPLC method. The plate has been pre-coated with human HIF-1a antibody. HIF-1a presents in the sample is added and binds to antibodies coated on the wells instead use then biotinylated human HIF-1a. The antibody is added and binds to HIF-1a in the sample. The substrate solution is then added, and color develops in proportion to the amount of human HIF-1 $\alpha$. The reaction is terminated by the addition of acidic stop solution, and absorbance is measured at $450 \mathrm{~nm}$. Intra-assay and inter-assay coefficients of variation for HIF- $1 \alpha$ were $<8 \%$ and $<10 \%$, respectively.

\section{Statistical analysis}

SPSS version 24.0 (SPSS Inc., Chicago, Illinois) statistical software was used for statistical analysis. All the variables in this sample of the study were tested by Shapiro-Wilk, the normal distribution variables $(p>0.005)$ were tested by parametric correlation test, but the abnormal distribution variables $(p<0.005)$ were tested by non-parametric test. 


\section{Results}

All the subjects of this study 89 samples, average $38-77$ years old, consist of 36 males (40.4\%) and 53 females (59.6\%). The subjects of this study were 40 samples with T2DM with malignancy and 49 samples without malignancy. The characteristics of the subjects of the study are included in Tables 1 and 2, BMl of the Group 1 was $24.89 \pm 4.59 \mathrm{~kg} / \mathrm{m}^{2}$ that subjects were normal and preobese group; according to the $\mathrm{WHO}$, the BMI of the subjects at the samples with T2DM without malignancy was $25.78 \pm 4.59 \mathrm{~kg} /$ $\mathrm{m}^{2}$ that subjects were a normal and preobese group.

Table 1. Characteristic of samples of diabetes mellitus Type 2 with malignancy (group 1) $(n=40)$

\begin{tabular}{lllll}
\hline Parameter & Minimum & Maximum & Mean & SD \\
\hline Age (years) & 37 & 73 & 56.90 & 8.75 \\
BMI $\left(\mathrm{kg} / \mathrm{m}^{2}\right)$ & 19.53 & 37.78 & 24.89 & 4.59 \\
FBS $(\mathrm{mg} / \mathrm{dl})$ & 83 & 635 & 260.45 & 105.55 \\
Hba1c $(\%)$ & 2.4 & 12.70 & 7.57 & 2.26 \\
HIF- $1 \alpha(\mathrm{ng} / \mathrm{ml})$ & 0.0 & 17.80 & 1.67 & 3.73 \\
\hline
\end{tabular}

The minimum of the FBS levels in the subjects with T2DM with malignancy was $83 \mathrm{mg} / \mathrm{dl}$ and the maximum was $635 \mathrm{mg} / \mathrm{dl}$ and the minimum of the FBS levels of the subjects with T2DM without malignancy was 87 $\mathrm{mg} / \mathrm{dl}$ and the maximum of the FBS levels was 500 $\mathrm{mg} / \mathrm{dl}$. In the both of the samples group we found average hyperglycemia. The mean of the $\mathrm{HbA} 1 \mathrm{c}$ value in the subjects of type DM with malignancy was 7.57 $\pm 2.26 \%$ which should be good and the bad level of the glycemic control. However, the mean of the $\mathrm{HbA} 1 \mathrm{c}$ of the subject of T2DM without malignancy was 9.34 $\pm 1.62 \%$ which means that all the subjects had bad glycemic control. T2DM with malignancy found the HIF-1 $\alpha$ in relative small $(0.000)$ accounts in the plasma until the high concentration of HIF-1a (17.80 ng/ml). In

Table 2. Characteristic of samples of diabetes mellitus type 2 without malignancy (group 2) $(n=49)$

\begin{tabular}{lllll}
\hline Parameter & Minimum & Maximum & Mean & SD \\
\hline Age (years) & 38 & 77 & 59.31 & 8.1 \\
BMI $\left(\mathrm{kg} / \mathrm{m}^{2}\right)$ & 18.55 & 41.84 & 25.78 & 4.59 \\
FBS $(\mathrm{mg} / \mathrm{dL})$ & 87 & 500 & 229.76 & 89.46 \\
Hba1c $(\%)$ & 6.10 & 14 & 9.34 & 1.62 \\
HIF-1a $(\mathrm{ng} / \mathrm{mL})$ & 0.0 & 3.16 & 0.69 & 0.84 \\
\hline
\end{tabular}

\begin{tabular}{lll}
\hline Non-parametric correlation & & \\
\hline Correlations & HIF-1a & Hba1c \\
\hline Spearman's rho & & \\
HIF-1a & 1.000 & -0.111 \\
$\quad$ Correlation coefficient & - & 0.301 \\
Sig. (two-tailed) & 89 & 89 \\
N & & \\
Hba1c & -0.111 & 1.000 \\
Correlation coefficient & 0.301 & - \\
Sig. (two-tailed) & 89 & 89 \\
N & & \\
\hline
\end{tabular}

\begin{tabular}{lll}
\hline Parametric correlation & & \\
\hline Correlations & FBS & Hba1c \\
\hline Spearman's rho & & \\
FBS & 1.000 & $0.292^{* *}$ \\
Correlation coefficient & - & 0.005 \\
Sig. (two-tailed) & 89 & 89 \\
N & & 1.000 \\
Hba1c & $0.292^{* *}$ & - \\
Correlation coefficient & 0.005 & 89 \\
Sig. (two-tailed) & 89 & \\
N & 8.01 level (two-tailed).
\end{tabular}

the samples of T2DM without malignancy we found relative small HIF-1a levels in the plasma (0.00) and the highest of the HIF-1a levels in the plasma (3.16 ng/ $\mathrm{mL}$ ). All the subjects were found that the HIF-1a levels were highest at the subjects of DM with malignancy. But by statistics, we found that there was no significant difference between HIF-1 $\alpha$ at the subjects at T2DM with malignancy without malignancy $(p=0.005)$.

In this study, we found that there was no significant correlation between HIF-1a with FBS and HbA1c ( $p>0.005$ ), but we found that there was a significant correlation $\mathrm{HbA} 1 \mathrm{c}$ with FBS $(p<0.005)$.

\section{Discussion}

Hyperglycemia was the characteristic of T2DM, and the previous studies with T2DM it was found increasing HIF-1 1 levels, indicated a state of the severity of DM [26]. T2DM with retinopathy was associated with the increased plasma HIF-1a levels and indicate that diabetic retinopathy will occur in the future and at the advanced retinopathy, because the average HIF-1a level was higher than that of the mild retinopathy group. Low or normal plasma HIF-1a levels depended on the degree of diabetic retinopathy [27]. HIF-1 $\alpha$ levels do not have a relationship with microalbuminuria and interactions with microalbuminuria with retinopathy [28]. Research by Zhang et al. said that hyperglycemia was significantly increasing HIF-1a [29]. Other studies showed that hyperglycemia and hypoxia were suspected to play a role in the pathophysiology of DM complications, due to the defective response of cells to low oxygen pressure [30]. Research by Sergiu-Bog and Catrina et al. said that primarily endothelial cells and dermal fibroblasts, hyperglycemia interferes with the function of induced hypoxia factor-1 alpha, which is a transcriptional factor in response to cell adaptation to the hypoxia process [31]. The occurrence of hypoxia is due to inadequate perfusion in adipose that has hyperplasia or hypertrophy. DM has a higher risk of malignancy compared to populations that do not have diabetes. Diabetes the risk of the some malignancies and also the negative prognosis affects people with DM after the diagnosed [32]. Patients with diabetes have a higher risk than the population without diabetes to suffer from cancer of the urinary tract, liver, bile ducts, pancreas, colon, endometrium, and kidneys [33], [34].

Long before HIF-1a was discovered in 1927 by Warburg et al. the observation that a malignancy occurred that produce high levels of lactate even in the presence of abundant oxygen [35]; he attributed this unusual form of aerobic glycolysis to mitochondrial injury. This glycolytic shift has been observed in dozens of cancers where rates of glycolysis may be 200 times higher than in non-cancer cells [36]. The 
previous studies found that hypoxia activated HIF-1a which results in the control of the post-ischemia revascularization process [37]. Recent research has revealed that destabilization of HIF-1a was most likely an event that transduced that hyperglycemia into a loss of cellular response to hypoxia in most diabetic complications [38]. HIF-1a levels decrease on biopsy of foot ulcers in patients with DM compared to venous ulcers that have the same hypoxic environment, but are not exposed to hyperglycemia. Decreased regulation of HIF-1a in response to hyperglycemia also appears to be responsible for the decrease in collateral growth triggered by myocardial ischemia in patients with DM [35]. Research by Jiang et al. found that a significantly increased HIF-1a levels in diabetics who were carried out in a cohort study, and followed by increased of the vascular endothelial growth factor (VEGF) [11]. This study also showed a positive correlation between serum VEGF and HIF-1a in patients with DM, presumably due to extensive HIF-1a role in regulating VEGF expression in diabetes. It was shown that HIF-1a, as a master regulator of cell response to hypoxic stress, plays important roles in breast cancer metastasis too [39]. We reported in this study this point of view by demonstrating that hypoxia/HIF-1 induces cancer stemlike cells by Jagged2 or mediates paracrine signaling between breast cancer cells and mesenchymal stem cells to promote metastasis [40]. However, this study did not show a significant correlation between HIF-1a with $\mathrm{HbA} 1 \mathrm{c}$ or with FBS ( $p>0.005)$. However, the results showed a significant correlation between $\mathrm{HbA} 1 \mathrm{c}$ and FBS ( $p<0.005$ ), where $r^{2}=0.087$, where FBS affected $\mathrm{HbA} 1 \mathrm{c} 8.7 \%$, and the rest was influenced by other factors. However, almost all samples of the study were found to have HIF-1a levels with different concentration levels, where the presence of HIF-1a was indicated the presence of hypoxic areas. In our study, we only classified the samples in two groups of Type 2 DM - with malignancy and without malignancy. However, both groups showed the levels of HIF-1a with different concentrations with the minimum values in the groups being the same, but the maximum values in the two groups were very different, where the maximum values in the T2DM group were much higher than those in the DM group without malignancy [41], [42].

\section{Conclusion}

It can be concluded that high levels of HIF-1a in DM samples with malignancy indicate the severity of the disease and the malignancy process suffered by the sample due to the ongoing hypoxia process. In spite of the high levels of the DM group without malignancy, we cannot conclude that they will experience a malignancy process, as well as there are still many factors involved. The higher levels of HIF-1a from the samples will experience a higher risk of getting a disease complication compared to the HIF-level with low $1 \alpha$.

\section{Acknowledgments}

The authors gratefully acknowledge that the present research is supported by the Ministry of Research and Technology and Higher Education Republic, Indonesia. The support is under the research grant TALENTA USU of the year 2019.

\section{References}

1. Kulie $T$, Slattengren A, Redmer J, Counts $H$, Eglash A Schrager S. Obesity and women's health: an evidence-based review. J Am Board Fam Med. 2011;24(1):75-85. https://doi. org/10.3122/jabfm.2011.01.100076

PMid:21209347

2. American Diabetes Association. Diagnosis and Classification of diabetes Mellitus. New York: American Diabetes Association; 2009.

3. Republik Indonesia. Badan Penelitian dan Pengembangan Kesehatan Kementrian Kesehatan. Jakarta, Indonesia: Republik Indonesia; 2013.

4. International Diabetes Federation. Riset Kesehatan Dasar Jakarta. F Diabetes Atlas. International Diabetes Federation; 2013. Available from: http://www.idf.org/diabetesatlas. [Last accessed on 2019 Mar 10].

5. Martin A, Komada MR, Sane DC. Abnormal angiogenesis in diabetes mellitus. Med Res Rev. 2003;23(2):117-45. https://doi. org/10.1002/med.10024

PMid:12500286

6. Onitilo AA, Engel JM, Glurich I, Stankowski RV, Williams GM Doi SA. Diabetes and cancer I: Risk, survival, and implications for screening. Cancer Causes Control. 2012;23(6):967-81. https://doi.org/10.1007/s10552-012-9972-3 PMid:22552844

7. García-Jiménez C, García-Martínez JM, Chocarro-Calvo A, De la Vieja A. A new link between diabetes and cancer: Enhanced WNT/ 3 -catenin signaling by high glucose. J Mol Endocrinol. 2014;52(1):R51-66. https://doi.org/10.1530/ jme-13-0152

PMid:24049067

8. Stocks T, Rapp K, Bjørge T, Manjer J, Ulmer H, Selmer R, et al. Blood glucose and risk of incident and fatal cancer in the metabolic syndrome and cancer project (Me-Can): Analysis of six prospective cohorts. PLoS Med. 2009;6(12):e1000201. https://doi.org/10.1371/journal.pmed.1000201

PMid:20027213

9. Muti P, Quattrin T, Grant BJ, Krogh V, Micheli A, Schünemann $\mathrm{HJ}$, et al. Fasting glucose is a risk factor for breast cancer: A prospective study. Cancer Epidemiol Biomarkers Prev. 2002;11:1361-8.

PMid:12433712

10. Saydah SH, Platz EA, Rifai N, Pollak MN, Brancati FL, 
Helzlsouer KJ. Association of markers of insulin and glucose control with subsequent colorectal cancer risk. Cancer Epidemiol Biomarkers Prev. 2003;12(5):412-8.

PMid: 12750235

11. Jiang $Y$, Ben $Q$, Shen $H$, Lu W, Zhang $Y$, Zhu J. Diabetes mellitus and incidence and mortality of colorectal cancer: A systematic review and meta-analysis of cohort studies. Eur J Epidemiol. 2011;26(11):863-76. https://doi.org/10.1007/ s10654-011-9617-y

PMid:21938478

12. Noto H, Tsujimoto T, Sasazuki T, Noda M. Significantly increased risk of cancer in patients with diabetes mellitus: A systematic review and meta-analysis. Endocr Pract. 2011;17(4):616-28. https://doi.org/10.4158/ep10357.ra PMid:21454235

13. Min $\mathrm{H}$, Kornelia P. Microenvironmental regulation of cancer development. Curr Opin Genet Dev. 2008;18(1):27-34. https:// doi.org/10.1016/j.gde.2007.12.006

14. Pernicova I, Korbonits M. Metformin: Mode of action and clinical implications for diabetes and cancer. Nat Rev Endocrinol. 2014;10(3):143-56. https://doi.org/10.1038/nrendo.2013.256 PMid:24393785

15. Bodmer M, Meier C, Krahenbuhl S, Jick SS, Meier CR. Longterm metformin use is associated with decreased risk of breast cancer. Diabetes Care. 2010;33:1304-8. https://doi.org/10.2337/ dc09-1791

PMid:20299480

16. Krentz AJ, Bailey CJ. Oral antidiabetic agents: Current role in Type 2 diabetes mellitus. Drugs. 2005;65:385-411. https://doi. org/10.2165/00003495-200565030-00005 PMid: 15669880

17. Franciosi M, Lucisano G, Lapice E, Strippoli GF, Pellegrini F, Nicolucci A. Metformin therapy and risk of cancer in patients with Type 2 diabetes: Systematic review. PLoS One. 2013;8:e71583. https://doi.org/10.1371/journal.pone.0071583 PMid:23936520

18. Zordoky BN, Bark D, Soltys CL, Sung MM, Dyck JR. The antiproliferative effect of metformin in triple-negative MDA-MB-231 breast cancer cells is highly dependent on glucose concentration: implications for cancer therapy and prevention. Biochim Biophys Acta. 2014;1840(6):1943-57. https://doi.org/10.1016/j. bbagen.2014.01.023 PMid:24462945

19. Ece H, Cigdem E, Yuksel K, Ahmet D, Hakan E, Oktay TM. Use of oral antidiabetic drugs (Metformin and Pioglitazone) in diabetic patients with breast cancer: How does it effect on serum Hif-1 alpha and 8Ohdg levels? Asian Pac J Cancer Prev. 2012;13(10):5143-8. https://doi.org/10.7314/ apjcp.2012.13.10.5143

PMid:23244125

20. Giovannucci E. Insulin, insulin-like growth factors and colon cancer: A review of the evidence. J Nutr. 2001;131(11 Suppl):3109S-20S. https://doi.org/10.1093/ jn/131.11.3109s PMid:11694656

21. Hirsch HA, lliopoulos D, Tsichlis PN, Struhl K. Metformin selectively targets cancer stem cells, and acts together with chemotherapy to block tumor growth and prolong remission. Cancer Res. 2009;69(19):7507-11. https://doi.org/10.1158/00085472.can-09-2994

PMid:19752085

22. Mcpherson K, Steel CM, Dixon JM. 5 Breast cancer epidemiology, risk factors, and genetics. $A B C$ of Breast Dis. 2009;572:24.

23. Giovannucci E, Harlan DM, Archer MC, Bergenstal RM,
Gapstur SM, Habel LA, et al. Diabetes and cancer: A consensus report. CA Cancer J Clin. 2010;60(4):207-21. PMid:20554718

24. Katherine LT, Turley H, Gatter KC, Maxwell PH, Pugh CW, Ratcliffe $\mathrm{PJ}$, et al. The expression and distribution of the hypoxia-inducible factors HIF-1 $\alpha$ and HIF- $2 \alpha$ in normal human tissues, cancers, and tumor-associated macrophages. Am J Pathol. 2000;157(2):411-21. https://doi.org/10.1016/ s0002-9440(10)64554-3 PMid: 10934146

25. Harding JL, Shaw JE, Peeters A, Cartensen B, Magliano DJ. Cancer risk among people with Type 1 and Type 2 diabetes: Disentangling true associations, detection bias, and reverse causation. Diabetes Care. 2015;38(2):264-70. https://doi. org/10.2337/dc14-1996

PMid:25488912

26. Li QF, Xu H, Sun $Y, H u R$, Jiang $H$ Induction of inducible nitric oxide synthase by isoflurane post-conditioning via hypoxia inducible factor1aduring tolerance against ischemic neuronal injury. Brain Res. 2012;1451:1-9. https://doi.org/10.1016/j. brainres.2012.02.055

PMid:22445062

27. Thangarajah H, Yao D, Chang El, Shi Y, Jazayeri L, Vial IN et al. The molecular basis for impaired hypoxia-induced VEGF expression in diabetic tissues. Proc Natl Acad Sci USA. 2009;106(32):13505-1. https://doi.org/10.1073/ pnas.0906670106 PMid:19666581

28. Hoo Y, Mahmoud AA. Hypoxia inducible factor-1a in Type 2 diabetes mellitus with microalbuminuria and retinopathy. Majalah Kedokt Bandung Bandung Med J. 2014;46(2):100-5. https://doi.org/10.15395/mkb.v46n2.281.

29. Lin M, Chen Y, Jin J, Hu Y, Zhou KK, Le YZ, et al. Ischaemiainduced retinal neovascularisation and diabetic retinopathy in mice with conditional knockout of hypoxia-inducible factor-1 in retinal Muller cells. Diabetologia. 2011;54(6):1554-66. https:// doi.org/10.1007/s00125-011-2081-0 PMid:21360191

30. Liang J, Qian $Y, X u$ D, Yin Q, Pan HJ. Serum tumor markers: Hypoxiainducible factor- $1 \alpha$ HIF-1 $1 \alpha$ and vascular endothelial growth factor, in patients with non-small cell lung cancer before and after intervention. Asian Pac J Cancer Prev. 2013;14(6):3851-4. https://doi.org/10.7314/apjcp.2013.14.6.3851 PMid:23886195

31. Zhang Z, Yan J, Shi H. Role of hypoxia inducible factor 1 in hyperglycemia exacerbated blood-brain barrier disruption in ischemic stroke. HHS Public Access. 2016;95:82-9. https://doi. org/10.1016/j.nbd.2016.07.012 PMid:27425889

32. Bento CF, Pereira P. Regulation of hypoxia-inducible factor 1 and the loss of the cellular response to hypoxia in diabetes. Diabetologia. 2011;54:1946-56. https://doi.org/10.1007/ s00125-011-2191-8

PMid:21614571

33. Catrina SB, Okamoto K, Pereira T, Brismar K, Poellinger L. Hyperglycemia regulates hypoxia-inducible factor-1alpha protein stability and function. Diabetes. 2004;53(12):3226-32. https://doi.org/10.2337/diabetes.53.12.3226 PMid: 15561954

34. Scheid A, Wenger RH, Schaffer L, Camenisch I, Distler O, Ferenc A, et al. Physiologically low oxygen concentrations in fetal skin regulate hypoxia-inducible factor 1 and transforming growth factor-3. FASEB J. 2002;16(3):411-3. https://doi. org/10.1096/fj.01-0496fje

PMid:11790723 
35. Warburg O, Wind F, Negelein E. The metabolism of tumors in the body. J Gen Physiol. 1927;8(6):519-30. https://doi.org/10.1085/ jgp.8.6.519

PMid:19872213

36. Vigneri P, Frasca F, Sciacca L, Pandini G, Vigneri R. Diabetes PMid: 19620249

37. Chaturvedi P, Gilkes DM, Wong CC, Luo W, Zhang H, Wei $\mathrm{H}$, et al. Hypoxia- inducible factor-dependent breast cancermesenchymal stem cell bidirectional signaling promotes metastasis. J Clin Invest. 2013;123(1):189-205. https://doi. org/10.1158/1538-7445.am2013-505

PMid:23318994

38. Yeung SJ, Pan J, Lee MH. Roles of p53, Myc and HIF-1 in regulating glycolysis: The seventh hallmark of cancer. Cell Mol Life Sci. 2008;65(24):3981-999. https://doi.org/10.1007/ s00018-008-8224-x

PMid: 18766298

39. Zhang H. HIF-1 suppresses lipid catabolism to promote cancer progression. Mol Cell Oncol. 2015;2(4):980184. https://doi.org/

\section{$10.4161 / 23723556.2014 .980184$ \\ PMid:27308514}

40. Sakkinen PA, Wahl P, Cushman M, Lewis MR, Tracy RP. Clustering of procoagulation, inflammation, and fibrinolysis variables with metabolic factors ininsulin resistance syndrome. Am J Epidemiol. 2000;152(10):897-907. https://doi.org/10.1093/ aje/152.10.897

PMid:11092431

41. Jiang F, Tang YT, Guo L, Jiao XY. The role of insulin-like growth factor $\mathrm{i}$ and hypoxia inducible factor $1 \alpha$ in vascular endothelial growth factor expression in Type 2 diabetes. Ann Clin Lab Sci. 2013;43(1):37-44. https://doi.org/10.1161/ hypertensionaha.115.06412

\section{PMid:23462604}

42. Xing F, Okuda H, Watabe M, Kobayashi A, Pai SK, Liu W, et al Hypoxia induced Jagged2 promotes breast cancer metastasis and self-renewal of cancer stem-like cells. Oncogene. 2011;30(39):4075-86. https://doi.org/10.1038/onc.2011.122

PMid:21499308 